\title{
HEMATOLOGICAL AND BIOCHEMICAL IMPROVEMENT BY CATECHIN AND EDTA IN LEAD INTOXICATED RATS
}

\author{
WAFFA HASSANIN MOHAMED ${ }^{1}$; MANAL MOHAMED SAYED ${ }^{2}$; AHMED ABD ELBAKY \\ SHARKAWY ${ }^{3}$; DOHA YEHIA AHMED ${ }^{3}$ and HOSSAM MOHAMED OMAR ${ }^{4}$ \\ ${ }^{1}$ Department of Toxicology and Forensic Medicine, Faculty of Veterinary Medicine, Aswan University. \\ ${ }^{2}$ Department of Chemistry, Animal Health Research Institute, Assiut Lab. \\ ${ }^{3}$ Department of Toxicology and Forensic Medicine, Faculty of Veterinary Medicine, Assiut University. \\ ${ }^{4}$ Department of Zoology, Faculty of Science, Assiut University.
}

Received: 31 December 2016; $\quad$ Accepted: 30 January 2017

\begin{abstract}
The present study was conducted to evaluate the efficacy of both Catechin and Calcium Disodium Ethylene diamine Tetraacetic Acid $\left(\mathrm{CaNa}_{2}\right.$ EDTA) in treatment of long-term lead toxicity through assessment of some biochemical indices (hematological picture and biochemical parameters). Eighty male albino rats weighting 100 $150 \mathrm{~g}$ of 10-12 weeks old were randomly divided into 4 groups (20 each). Group 1 was left without any treatment as negative control group. The other three groups (G2, G3 and G4) were exposed to lead acetate in drinking water at a concentration of $30 \mathrm{mg} / \mathrm{L}$ for 3 months. G2 was used as positive conrol group. G3 was divided into three subgroups A, B \& $\mathrm{C}$ was treated with catechin in drinking water at a concentration of 49 $\mathrm{mg} / \mathrm{L}$ for 7 days after 1, 2 and 3 month after $\mathrm{Pb}$ exposure, respectively. G4 was also divided into three subgroups $\left(\mathrm{D}, \mathrm{E} \& \mathrm{~F}\right.$ ) and treated through IP injection $\mathrm{CaNa}_{2}$ EDTA in a dose of $50 \mathrm{mg} / \mathrm{kg}$ body weight, for 5 days after 1 , $2 \& 3$ months of lead exposure. Six rats were taken randomly after 30, 60 and 90 days from negative and positive controls, 37, 67, 97 days from rats treated with catechin and 35, 65 and 95 days from rats treated with $\mathrm{CaNa}_{2}$ EDTA. Rats were anesthetized with ether and sacrified for blood and tissues collection. Blood samples were collected in vacutainer tubes containing EDTA as anticoagulant for hematological pictures. Brain tissue samples were collected from each rat for the subsequent biochemical parameters (total protein, nitric oxide, lipid peroxidation, glutathione, superoxide dismutase, catalase, glucose 6 phosphatase dehydratase and, acetylcholinestrase activity). The results revealed that administration of catechin or $\mathrm{CaNa}_{2} \mathrm{EDTA}_{\mathrm{T}}$ can minimize any toxic effects on hematological picture \& biochemical parameters. Catechin was more effective than $\mathrm{CaNa}_{2}$ EDTA in improvement of $\mathrm{Hb}$ concentration, $\mathrm{HCT} \%, \mathrm{MCV}, \mathrm{MCH}$ values and NO, LPO parameters but $\mathrm{CaNa}_{2}$ EDTA was more effective than Catechin in improvement of WBCs, lymphocyte, monocyte count and GSH, SOD, CAT activities.
\end{abstract}

Key Words: Hematological, Biochemical, Catechin, EDTA, Lead and Rats.

\section{INTRODUCTION}

In recent years, the level of heavy metals, particularly lead $(\mathrm{Pb})$ has increased in air, water and soil in both urban and peri-urban areas (Gupta, 2007). Heavy metals induce toxic effects on different systems and apparatuses. Furthermore, because of their long half-life, heavy metals also induce accumulation phenomena, which in turn produce increase of their concentration in blood and tissues. Among heavy metals, $\mathrm{Pb}$ represents the main environmental pollutant is a non essential toxic heavy metal widely distributed in the environment

Corresponding author: Dr. MANAL MOHAMED SAYED

E-mail address: sary64@windowslive.com

Present address: Department of Chemistry, Animal Health Research Institute, Assiut Lab and causes neurological impairment (Soong et al., 1999). The main sources of environmental $\mathrm{Pb}$ are from leaded gasoline, lead shots orbullets, soil, dust, toys, lead acid batteries, cosmeticsand paints (Thuppil and Tannir, 2013).Lead directly affects the hematopoietic system through restraining the synthesis of hemoglobin $(\mathrm{Hb})$ by inhibiting three vital enzymesin pathway of heme synthesis, $\delta$ aminolevulinic acid dehydratase, aminolevulinic acid synthetase, and the mitochondrial enzyme ferrochelatas that catalyzes the insertion of iron into protoporphyrin to form heme (Piomelli, 2002). It also reduces the life span of circulating erythrocytes by increasing the fragility of cell membranes these two processes leads to anemia (Guidotti et al., 2008). In more advanced cases of $\mathrm{Pb}$ toxicity, absolute neutrophilia, leukocytosis (with shifting to left), 
eosinopenia, and monocytopenia have been reported (Xintaras, 1992).

Lead induced oxidative stress by increased the levels of lipid peroxidation (LPO) or decrease in antioxidant defence mechanism (Bokara et al., 2008). Pb shows electron sharing capability that results in the formation of covalent attachments. These attachments are formed between the $\mathrm{Pb}$ moiety and sulfhydryl ($\mathrm{SH})$ groups present in antioxidant enzymes, which are the most susceptible targets for $\mathrm{Pb}$ and which eventually get inactivated (Flora et al., 2012). Pb binds exclusively to the $-\mathrm{SH}$ group, which decreases the Glutathione (GSH) levels and can interfere with the antioxidant activity of GSH (Bechara, 2004) and decrease Catalase (CAT) ,Superoxide dismutase (SOD) enzyme commonly found in living tissue (Patil et al., 2006).

Catechin (Green tea) is a free radical scavenger and can scavenge both hydroxyl and superoxide radicals as well as lipid free radicals and peroxyl radicals (Sutherland et al., 2006). The health-promoting effects of green tea are mainly attributed to its polyphenol content (Khan and Mukhtar, 2007). The major tea catechins are (-)-epigallocatechin-3-gallate, (-)-epicatechin-3-gallate, (-)- epigallocatechin, (-)epicatechin, (+)-gallocatechin, and (+)-catechin (Kaushik et al., 2011). Moreover, green tea extracts and its isolated constituents are effective in preventing oxidative stress (Babu et al., 2006) and neurological problems (Unno et al., 2007). Intake of green tea extracts also increases the activity of SOD in serum and the expression of CAT in the aorta; these enzymes are implicated in cellular protection against reactive oxygen species (ROS) (Skrzydlewska et al., 2002).

Calcium Disodium Ethylene diamine Tetraacetic Acid $\left(\mathrm{CaNa}_{2}\right.$ EDTA) is the most commonly used chelating agent. It is a derivative of ethylenediaminete traacetic acid; a synthetic polyamino-polycarboxylic acid which was used for the treatment of metal poisoning and had been the mainstay of chelation therapy for many years (Kalia and Flora, 2005).

Aim of the study to evaluate the protective effects of both Catechin and Calcium Disodium Ethylene diamine Tetraacetic Acid $\left(\mathrm{CaNa}_{2}\right.$ EDTA) in treatment of long-term lead toxicity through assessment of some biochemical indices (hematological picture and biochemical parameters).

\section{MATERIALS AND METHODS:}

Chemicals:-

1- Catechin, $\left(\mathrm{C}_{15} \mathrm{H}_{14} \mathrm{O}\right)$ and $98 \%$ purity was obtained from Sigma chemicals Co., USA.

2- Calcium disodium ethylenediamine tetraacetic acid (Calcium disodium EDTA), $\mathrm{C}_{10} \mathrm{H}_{12} \mathrm{~N}_{2} \mathrm{O}_{8} \mathrm{Ca}$
$\mathrm{Na}_{2} \cdot 2 \mathrm{H}_{2} \mathrm{O}$ and purity $95 \%$, was obtained from LAB-Chemical, India.

3- Lead acetate $\left[\mathrm{Pb}\left(\mathrm{CH}_{3} \mathrm{COO}\right)_{2} .3 \mathrm{H}_{2} \mathrm{O}\right]$ with molecular weight of 379.33 was obtained from EL Nasr Pharmaceutical Chemicals Co., Egypt.

\section{Animals:}

Eighty male albino rats weighting $100-150 \mathrm{~g}$ of $10-12$ weeks old were obtained from the Laboratory Animals House, Faculty of Medicine, Assiut University. The rats were housed in plastic cages, five rats each. Animals were acclimatized to laboratory condition two weeks before the experiment and fed commercial pellet rat feed. Feed and water were available add libitum, suitable temperature and lighting cycle of 12 hours (light/dark) were also in consideration.

\section{Experimental Design:}

The obtained rats were randomly divided into 4 groups (20 each). Group 1 was left without any treatment as negative control. The other three groups (G2, G3 and G4) were exposed to lead acetate in drinking water at a concentration of $30 \mathrm{mg} / \mathrm{L}$ according to (Sujatha et al., 2011) for 3 months. G2 was used as positive conrol group. G3 was divided into three subgroup (A, B and C)and treated with catechin in drinking water at a concentration of 49 $\mathrm{mg} / \mathrm{L}$ according to (Miltonprabu and Thangapandiyan, 2013) for 7 days after 1, 2 and 3 months post $\mathrm{Pb}$ exposure, respectively. $\mathrm{G} 4$ was also divided into three subgroup $(\mathrm{D}, \mathrm{E}$ and $\mathrm{F})$ and treated with calcium disodium EDTA in a dose of $50 \mathrm{mg} / \mathrm{kg}$ body weight, IP for 5 days after $1,2 \& 3$ months post lead exposure according to (Flora et al., 2007).

Time schedule for samples collection and preparation:

Samples were collected from six rats taken randomly 3 times with intervals at 30,60 and 90 days from negative and positive control 37, 67, 97 from rats treated with catechin and 35, 65 and 95 from rats treated samples were with calcium sodium EDTA. Rats were anesthetized with ether and sacrificed for blood and tissues collection. Blood samples were collected from medial canthus of orbital cavity of these rats in vacutainer tubes containing anticoagulant for hematological pictures.

Brain collected from each rat, washed with phosphate buffer $0.1 \mathrm{M} \mathrm{pH} 7.4$ and used for preparation of cytosol. $10 \%$ homogenate of brain samples were prepared by homogenization of $250 \mathrm{mg}$ of each tissue in $2.5 \mathrm{ml}(0.1 \mathrm{M})$ phosphate buffer $(\mathrm{pH} 7.4)$ using homogenizer (IKA Yellow line DI 18 Disperser, Germany). The homogenates were centrifuged at $6,000 \mathrm{rpm}$ for 1 hour at $4{ }^{\circ} \mathrm{C}$ and the supernatant cytosols were kept frozen at $-20{ }^{\circ} \mathrm{C}$ for the subsequent biochemical parameters (total protein, nitric oxide, lipid peroxidation, glutathione, superoxide dismutase, 
catalase, glucose 6 phosphatase dehydratase, acetylcholinestrase activity).

\section{Hematological parameters:}

Complet blood picture was performed by Haematological Analizar (Media Serve, Exigo Haematology Analizar) at Pathology and Clínical Pathology Department, Faculty of Veterinary, Assiut University.

\section{Biochemical parameters:}

\section{1-Assessment of total protein:}

Total protein concentration in brain cytosol was determined by the method of Lowry et al. (1951).

\section{2- Assessment of NO:}

NO was measured as nitrite concentration in brain according to the method of Ding et al. (1988).

\section{3-Assessment of LPO:}

Product of LPO as TBARS in brain was estimated according to the method of ohkawa et al. (1979).

\section{4-Assessment of GSH:}

GSH content in brain was determined using the method of Beutler et al. (1963).

\section{5- Assessment of SOD activity:}

The activity of SOD in tissue cytosols was determined according to its ability to inhibit the autoxidation of epinephrine at alkaline medium according to the method of Misra and Fridovich (1972)

\section{6- Assessment of CAT activity:}

Activity of CAT in tissue cytosols was determined basing on its ability to decompose $\mathrm{H}_{2} \mathrm{O}_{2}$ according to Luck (1963).

\section{7- Assessment of G6PD activity:}

The activity of G6PD in tissue cytosols was determined according to its ability to reduce NADP according to the method of Haghighi et al. (1998).

\section{8- Assessment of AChE activity:}

AChE enzyme activity was estimated according the method of Ellman et al. (1961).

\section{Statistical analysis:}

The data was expressed as mean \pm SE. The results were analyzed statistically using one-way analysis of variance with Tukey and Dunnett multiple comparison tests as a post-tests. These analyses were carried out using the computer prism program for windows, version 6.0 (Graph pad software Inc., San Diego, California, USA) and the computer SPSS program for windows, version 16.0. Differences between and among the groups were considered significant if $P \leq 0.05$.

\section{RESULTS}

\section{Hematological parameters:}

In the present study, RBCs count showed significant decrease in $\mathrm{G} 2$ after three months post exposure in comparison with the negative control. However, there is significant increase in RBC count after three months in G3 and after 2nd and 3rd month in G4 in comparison with G2 (Table 1).

A significant decrease of $\mathrm{Hb}$ concentration was recorded during the whole period of the experiment in G2 when compared with the control group. In G3, Hb level showed a significant increase all over the the experiment period in comparison with $\mathrm{G} 2$. While $\mathrm{Hb}$ level was significantly increased after the end of $2^{\text {nd }}$ and $3^{\text {rd }}$ month in G4 when compared with G2 (Table 2).

Haematocrit (HCT) percent was significantly increased in G3 during all the experiment period and in $\mathrm{G} 4$ after the end of $2^{\text {nd }}$ month in comparison with G2 (Table3).

MCV values was significantly increased in G3 after three months although it showed a significant decrease after $2^{\text {nd }}$ month in G4 when compared with G2 (Table 4).

$\mathrm{MCH}$ showed a significant increase in G3 after $3^{\text {rd }}$ month when compared with G2 but it showed a significantldecrease after $2^{\text {nd }}$ and $3^{\text {rd }}$ month in G4when compared with the negative one (Table5).

In the present study, G3 showed significant decrease in WBC count after $1^{\text {st }}$ and $2^{\text {nd }}$ month and significantly increased after three months when compared with G2. In G4, a significant increase in WBC count was observed after $1^{\text {st }}$ and $2^{\text {nd }}$ month in comparison with control group and a significant increase all over the experiment period when compared with G2 and after $1^{\text {st }}$ and $2^{\text {nd }}$ month of treatment when compared with G3 (Table 6).

Lymphocyte count was significantly increased after three month In G3 and after $2^{\text {nd }}$ and $3^{\text {rd }}$ month in G4 when compared with G2 (Table7). However, granulocytes in G3 significantly decreased after $1^{\text {st }}$ month and increased after $3^{\text {rd }}$ month when compared with $\mathrm{G} 2$, while in $\mathrm{G} 4$, granulocyte count significantly decreased after $1^{\text {st }}$ month and increased after $2^{\text {nd }}$ and $3^{\text {rd }}$ month when compared with G2 (Table 8). In addition, the present study revealed a significant increase in monocyte count after three month in G3 and after $1^{\text {st }}$ and $2^{\text {nd }}$ month when compared with $\mathrm{G} 2$ (Table 9). 


\section{Biochemical parameters:}

In the present study, nitric oxide and lipid peroxidation levels in the brain tissue showed a significant increase in G2 (positive control) in comparison with negative control all over the experiment period. NO and LPO levels showed a significant decrease all over the experiment period in G3 when compared with G2. However, NO and LPO levels in G4 showed a significant decrease after 2 and 3 months of treatment (Table 10 and 11).

Data of the present study showed that GSH level in the brain tissue was significantly decreased after $1^{\text {st }}$ and $2^{\text {nd }}$ month in $\mathrm{G} 2$ in comparison to negative control. G3 and G4 showed significant increase in the levels of GSH all over the experiment period in comparison with G1 and G2 but G4 showed a significant increase in values of GSH after three months in comparison with G3 (Table 12).

In the present study SOD activity in brain tissue showed a significant increase in G3 after $1^{\text {st }}$ and $3^{\text {rd }}$ month in comparison with G1 and all over the experiment period when compared with G2. Also, in G4 a significant increase in SOD activity was found after $1^{\text {st }}$ month in comparison with G1 and all over the experiment period when compared with G2 and after $1^{\text {st }}$ month when compared with G3 (Table 13).

In the present study, the activity of CAT in brain tissue showed no significant change in G2.

G4 showed significant increase in CAT activity was found after $1^{\text {st }}$ and $2^{\text {nd }}$ month in comparison with G1 and all over the experiment period when compared with G2 and after $1^{\text {st }}$ month when compared to G3 (Table 14).

The activity of G6PD in brain showed no significant change in $\mathrm{G} 2$ while it was significantly increased post $1^{\text {st }}$ and $2^{\text {nd }}$ month in G3 and G4 in comparison with G1 and G2 but G4 showed a significant increase in values of G6PD activity post $1^{\text {st }}$ month in comparison with G3(Table 15).

AChE enzyme activity in brain tissue showed a significant increase in G3 after $2^{\text {nd }}$ and $3^{\text {rd }}$ month when compared with $\mathrm{G} 2$ and all over the experiment period in G4 in comparison with $\mathrm{G} 2$ and post $1^{\text {st }}$ month when compared to G3 (Table 16).

Table 1: Effect of catechin and EDTA in $\mathrm{RBC}_{\mathrm{S}}$ count $\left(\right.$ million $\left./ \mathrm{mm}^{3}\right)$ of lead intoxicated rats $(\mathrm{n}=6)$.

\begin{tabular}{cccc}
\hline Exposed Groups & \multicolumn{3}{c}{ Post-exposure time (months) } \\
\cline { 2 - 4 } & $1^{\text {st }}$ & $2^{\text {nd }}$ & $3^{\text {rd }}$ \\
\hline G1 & $7.31 \pm 0.549$ & $7.17 \pm 0.553$ & $7.09 \pm 0.513$ \\
\hline G2 & $6.83 \pm 0.366$ & $6.59 \pm 0.336$ & $5.26 \pm 0.149 \mathrm{a}$ \\
\hline G3 & $7.51 \pm 0.097$ & $8.06 \pm 0.163$ & $8.26 \pm 0.318 \mathrm{~b}$ \\
\hline G4 & $7.82 \pm 0.134$ & $8.65 \pm 0.489 \mathrm{~b}$ & $7.63 \pm 0.265 \mathrm{~b}$ \\
\hline
\end{tabular}

All values was expressed as (meen $\pm \mathrm{SE}$ )

a significant at $\mathrm{p} \leq .05$ in comparison with control group

$b$ indicates significant difference with $\mathrm{G} 2$

c indicates significant difference between G3 and G4

Table 2: Effect of catechin and EDTA in Hb values $(\mathrm{g} / \mathrm{dl})$ of lead exposed rats $(\mathrm{n}=6)$.

\begin{tabular}{cccc}
\hline \multirow{2}{*}{ Exposed Groups } & \multicolumn{3}{c}{ Post-exposure time (months) } \\
\cline { 2 - 4 } & $1^{\text {st }}$ & $2^{\text {nd }}$ & $14.16 \pm 0.366$ \\
\hline$G 1$ & $14.06 \pm 0.440$ & $13.66 \pm 0.185$ & $10.46 \pm 0.284 \mathrm{a}$ \\
\hline G2 & $11.33 \pm 0.517 \mathrm{a}$ & $11.93 \pm 0.233 \mathrm{a}$ & $14.23 \pm 0.578 \mathrm{~b}$ \\
\hline G3 & $13.50 \pm 0.351 \mathrm{~b}$ & $14.16 \pm 0.272 \mathrm{~b}$ & $12.96 \pm 0.742 \mathrm{~b}$ \\
\hline G4 & $13.10 \pm 0.305$ & $14.80 \pm 0.500 \mathrm{~b}$ &
\end{tabular}

All values was expressed as (meen $\pm \mathrm{SE})$

a significant at $\mathrm{p} \leq .05$ in comparison with control group

b indicates significant difference with $\mathrm{G} 2$

c indicates significant difference between G3 and G4 
Table 3: Effect of catechin and EDTA in HCT\% of lead exposed rats $(n=6)$.

\begin{tabular}{cccc}
\hline Exposed Groups & \multicolumn{3}{c}{ Post-exposure time (months) } \\
\cline { 2 - 4 } & $1^{\text {st }}$ & $2^{\text {nd }}$ & $3^{\text {rd }}$ \\
\hline $\mathrm{G} 1$ & $43.10 \pm 0.351$ & $41.56 \pm 0.721$ & $43.96 \pm 0.218$ \\
\hline $\mathrm{G} 2$ & $35.03 \pm 0.517 \mathrm{a}$ & $34 \pm 0.305 \mathrm{a}$ & $32.50 \pm 0.550 \mathrm{a}$ \\
\hline $\mathrm{G} 3$ & $39.10 \pm 0.435 \mathrm{abc}$ & $38.96 \pm 0.233 \mathrm{ab}$ & $38.90 \pm 0.200 \mathrm{abc}$ \\
\hline $\mathrm{G} 4$ & $36.20 \pm 0.650 \mathrm{ac}$ & $37.76 \pm 0.54 \mathrm{ab}$ & $34.53 \pm 0.902 \mathrm{ac}$ \\
\hline
\end{tabular}

All values was expressed as (meen $\pm \mathrm{SE}$ )

a significant at $p \leq .05$ in comparison with control group

$\mathrm{b}$ indicates significant difference with $\mathrm{G} 2$

c indicates significant difference between G3 and G4

Table 4: Effect of catechin and EDTA in MCV $\left(u / \mathrm{mm}^{3}\right)$ of lead exposed rats $(n=6)$.

\begin{tabular}{cccc}
\hline \multirow{2}{*}{ Exposed Groups } & \multicolumn{3}{c}{ Post-exposure time (months) } \\
\cline { 2 - 4 } & $1^{\text {st }}$ & $2^{\text {nd }}$ & $3^{\text {rd }}$ \\
\hline G1 & $54.56 \pm 0.120$ & $52.56 \pm 0.497$ & $53.43 \pm 0.523$ \\
\hline G2 & $49.53 \pm 0.260 \mathrm{a}$ & $49 \pm 0.503 \mathrm{a}$ & $45.90 \pm 0.709 \mathrm{a}$ \\
\hline $\mathrm{G} 3$ & $50.80 \pm 0.608 \mathrm{a}$ & $49.23 \pm 0.924 \mathrm{ac}$ & $49.26 \pm 0.523 \mathrm{abc}$ \\
\hline $\mathrm{G} 4$ & $48.63 \pm 1.28 \mathrm{a}$ & $43.50 \pm 0.838 \mathrm{abc}$ & $45.20 \pm 0.351 \mathrm{ac}$ \\
\hline
\end{tabular}

All values was expressed as (meen $\pm \mathrm{SE})$

a significant at $\mathrm{p} \leq .05$ in comparison with control group

$b$ indicates significant difference with $\mathrm{G} 2$

c indicates significant difference between G3 and G4

Table 5: Effect of catechin and EDTA in MCH (pg) of lead exposed rats $(n=6)$.

\begin{tabular}{cccc}
\hline Exposed Groups & \multicolumn{3}{c}{ Post-exposure time (months) } \\
\cline { 2 - 4 } & $1^{\text {st }}$ & $2^{\text {nd }}$ & $3^{\text {rd }}$ \\
\hline G1 & $19.03 \pm 0.366$ & $18.90 \pm 0.378$ & $18.76 \pm 0.317$ \\
\hline G2 & $17.10 \pm 0.378 \mathrm{a}$ & $16.63 \pm 0.284 \mathrm{a}$ & $15.70 \pm 0.472 \mathrm{a}$ \\
\hline $\mathrm{G} 3$ & $18.13 \pm 0.328$ & $17.76 \pm 0.266$ & $17.90 \pm 0.115 \mathrm{~b}$ \\
\hline $\mathrm{G} 4$ & $17.86 \pm 0.497$ & $17.06 \pm 0.296 \mathrm{a}$ & $16.60 \pm 0.264 \mathrm{a}$ \\
\hline
\end{tabular}

All values was expressed as (meen $\pm \mathrm{SE}$ )

a significant at $\mathrm{p} \leq .05$ in comparison with control group

b indicates significant difference with $\mathrm{G} 2$

c indicates significant difference between G3 and G4

Table 6: Effect of catechin and EDTA in WBCs counts (thousand/mm ${ }^{3}$ ) of lead exposed rats $(\mathrm{n}=6)$

\begin{tabular}{cccc}
\hline Exposed Groups & \multicolumn{3}{c}{ Post-exposure time (months) } \\
\cline { 2 - 4 } & $1^{\text {st }}$ & $2^{\text {nd }}$ & $3^{\text {rd }}$ \\
\hline G1 & $7.63 \pm 0.375$ & $7.86 \pm 0.348$ & $8.06 \pm 0.120$ \\
\hline G2 & $9.33 \pm 0.145 \mathrm{a}$ & $6.33 \pm 0.176$ & $3.73 \pm 0.440 \mathrm{a}$ \\
\hline G3 & $6.00 \pm 0.115 \mathrm{abc}$ & $4.26 \pm 0.338 \mathrm{abc}$ & $7.10 \pm 0.404 \mathrm{~b}$ \\
\hline $\mathrm{G} 4$ & $11.50 \pm 0.556 \mathrm{abc}$ & $11.26 \pm 0.664 \mathrm{abc}$ & $7.40 \pm 0.585 \mathrm{~b}$ \\
\hline
\end{tabular}

All values was expressed as (meen $\pm \mathrm{SE}$ )

a significant at $\mathrm{p} \leq .05$ in comparison with control group

$b$ indicates significant difference with $\mathrm{G} 2$

c indicates significant difference between G3 and G4 
Table 7: Effect of catechin and EDTA in Lymphocyte counts (thousand/mm3) of lead exposed rats $(n=6)$.

\begin{tabular}{cccc}
\hline \multirow{2}{*}{ Exposed Groups } & \multicolumn{3}{c}{ Post-exposure time (months) } \\
\cline { 2 - 4 } & $1^{\text {st }}$ & $2^{\text {nd }}$ & $3^{\text {rd }}$ \\
\hline G1 & $5.20 \pm 0.115$ & $5.06 \pm 0.088$ & $5.63 \pm 0.088$ \\
\hline G2 & $6.03 \pm 0.202 \mathrm{a}$ & $3.73 \pm 0.218$ & $2.73 \pm 0.233 \mathrm{a}$ \\
\hline G3 & $5.26 \pm 0.202 \mathrm{c}$ & $2.63 \pm 0.176 \mathrm{ac}$ & $4.70 \pm 0.360 \mathrm{~b}$ \\
\hline G4 & $6.43 \pm 0.176 \mathrm{ac}$ & $8.76 \pm 0.666 \mathrm{abc}$ & $5.66 \pm 0.317 \mathrm{~b}$ \\
\hline
\end{tabular}

All values was expressed as (meen $\pm \mathrm{SE})$

a significant at $\mathrm{p} \leq .05$ in comparison with control group

$b$ indicates significant difference with $\mathrm{G} 2$

c indicates significant difference between G3 and G4

Table 8: Effect of catechin and EDTA in Granulocyte counts (thousand/mm3) of lead exposed rats ( $\mathrm{n}=6)$.

\begin{tabular}{cccc}
\hline Exposed Groups & \multicolumn{3}{c}{ Post-exposure time (months) } \\
\cline { 2 - 4 } & $1^{\text {st }}$ & $2^{\text {nd }}$ & $3^{\text {rd }}$ \\
\hline G1 & $1.33 \pm 0.088$ & $1.40 \pm 0.115$ & $1.46 \pm 0.088$ \\
\hline G2 & $2.60 \pm 0.057 \mathrm{a}$ & $0.866 \pm 0.066 \mathrm{a}$ & $0.800 \pm 0.057 \mathrm{a}$ \\
\hline $\mathrm{G} 3$ & $1.40 \pm 0.115 \mathrm{bc}$ & $1.10 \pm 0.057$ & $2.13 \pm 0.033 \mathrm{abc}$ \\
\hline $\mathrm{G} 4$ & $2.03 \pm 0.145 \mathrm{abc}$ & $1.26 \pm 0.066 \mathrm{~b}$ & $1.23 \pm 0.120 \mathrm{bc}$ \\
\hline
\end{tabular}

All values was expressed as (meen $\pm \mathrm{SE}$ )

a significant at $\mathrm{p} \leq .05$ in comparison with control group

$\mathrm{b}$ indicates significant difference with $\mathrm{G} 2$

c indicates significant difference between G3 and G4

Table 9: Effect of catechin and EDTA in Monocyte count (thousand $/ \mathrm{mm}^{3}$ ) of lead exposed rats $(\mathrm{n}=6)$.

\begin{tabular}{cccc}
\hline Exposed Groups & \multicolumn{3}{c}{ Post-exposure time (months) } \\
\cline { 2 - 4 } & $1^{\text {st }}$ & $2^{\text {nd }}$ & $3^{\text {rd }}$ \\
\hline G1 & $0.500 \pm 0.057$ & $0.400 \pm 0.057$ & $0.566 \pm 0.066$ \\
\hline G2 & $0.466 \pm 0.033$ & $0.366 \pm 0.033$ & $0.200 \pm 0.057 \mathrm{a}$ \\
\hline G3 & $0.600 \pm 0.057 \mathrm{c}$ & $0.533 \pm 0.033 \mathrm{c}$ & $0.466 \pm 0.066 \mathrm{~b}$ \\
\hline G4 & $0.900 \pm 0.057 \mathrm{abc}$ & $1.23 \pm 0.088 \mathrm{abc}$ & $0.433 \pm 0.033$ \\
\hline
\end{tabular}

All values was expressed as (meen $\pm \mathrm{SE}$ )

a significant at $\mathrm{p} \leq .05$ in comparison with control group

$\mathrm{b}$ indicates significant difference with $\mathrm{G} 2$

c indicates significant difference between G3 and G4

Table 10: Effect of catechin and EDTA in nitric oxide concentration (nmol/mg protein) in brain cytosol of lead exposed rats $(n=6)$.

\begin{tabular}{cccc}
\hline Exposed Groups & \multicolumn{3}{c}{ Post-exposure time (months) } \\
\cline { 2 - 4 } & $1^{\text {st }}$ & $2^{\text {nd }}$ & $3^{\text {rd }}$ \\
\hline G1 & $10.45 \pm 0.386$ & $11.12 \pm 0.389$ & $11.45 \pm 0.386$ \\
\hline G2 & $18.20 \pm 0.275 \mathrm{a}$ & $17.26 \pm 0.754 \mathrm{a}$ & $22.82 \pm 1.78 \mathrm{a}$ \\
\hline G3 & $14.27 \pm 0.410 \mathrm{ab}$ & $9.56 \pm 0.427 \mathrm{~b}$ & $3.61 \pm 0.102 \mathrm{ab}$ \\
\hline G4 & $16.60 \pm 1.09 \mathrm{a}$ & $12.69 \pm 1.23 \mathrm{~b}$ & $6.18 \pm 0.370 \mathrm{ab}$ \\
\hline
\end{tabular}

All values was expressed as (meen $\pm \mathrm{SE}$ )

a significant at $\mathrm{p} \leq .05$ in comparison with control group

$\mathrm{b}$ indicates significant difference with $\mathrm{G} 2$

c indicates significant difference between G3 and G4 
Table 11: Effect of catechin and EDTA in lipid peroxide concentration (nmol/mg protein) in brain cytosol of lead exposed rats $(n=6)$.

\begin{tabular}{cccc}
\hline Exposed Groups & \multicolumn{3}{c}{ Post-exposure time (months) } \\
\cline { 2 - 4 } & $1^{\text {st }}$ & $2^{\text {nd }}$ & $3^{\text {rd }}$ \\
\hline G1 & $0.094 \pm 0.009$ & $0.091 \pm 0.005$ & $0.097 \pm 0.007$ \\
\hline$G 2$ & $1.44 \pm 0.080 \mathrm{a}$ & $1.85 \pm 0.079 \mathrm{a}$ & $2.18 \pm 0.080 \mathrm{a}$ \\
\hline $\mathrm{G} 3$ & $1.16 \pm 0.059 \mathrm{ab}$ & $1.37 \pm 0.088 \mathrm{ab}$ & $1.70 \pm 0.070 \mathrm{ab}$ \\
\hline $\mathrm{G} 4$ & $1.18 \pm 0.057 \mathrm{a}$ & $1.26 \pm 0.017 \mathrm{ab}$ & $1.56 \pm 0.064 \mathrm{ab}$ \\
\hline
\end{tabular}

All values was expressed as (meen $\pm \mathrm{SE}$ )

a significant at $\mathrm{p} \leq .05$ in comparison with control group

$b$ indicates significant difference with $\mathrm{G} 2$

c indicates significant difference between G3 and G4

Table 12: Effect of catechin and $\mathrm{CaNa}_{2}$ EDTA in GSH content (Micro nmol/mg protein) in brain cytosol of lead exposed rats $(n=6)$.

\begin{tabular}{cccc}
\hline \multirow{2}{*}{ Exposed Groups } & \multicolumn{3}{c}{ Post-exposure time (months) } \\
\cline { 2 - 4 } & $1^{\text {st }}$ & $2^{\text {nd }}$ & $3^{\text {rd }}$ \\
\hline G1 & $0.260 \pm 0.023$ & $0.250 \pm 0.025$ & $0.276 \pm 0.021$ \\
\hline G2 & $0.165 \pm 0.019 \mathrm{a}$ & $0.139 \pm 0.015 \mathrm{a}$ & $0.222 \pm 0.022$ \\
\hline G3 & $1.50 \pm 0.012 \mathrm{ab}$ & $0.887 \pm 0.036 \mathrm{ab}$ & $0.686 \pm 0.099 \mathrm{abc}$ \\
\hline G4 & $1.49 \pm 0.012 \mathrm{ab}$ & $0.946 \pm 0.013 \mathrm{ab}$ & $0.954 \pm 0.053 \mathrm{abc}$ \\
\hline
\end{tabular}

All values was expressed as (meen $\pm \mathrm{SE})$

a significant at $\mathrm{p} \leq .05$ in comparison with control group

$\mathrm{b}$ indicates significant difference with $\mathrm{G} 2$

c indicates significant difference between G3 and G4

Table 13: Effect of catechin and EDTA in SOD activity (unit/mg protein) in brain cytosol of lead exposed rats $(n=6)$.

\begin{tabular}{cccc}
\hline \multirow{2}{*}{ Exposed Groups } & \multicolumn{3}{c}{ Post-exposure time (months) } \\
\cline { 2 - 4 } & $1^{\text {st }}$ & $2^{\text {nd }}$ & $3^{\text {rd }}$ \\
\hline G1 & $2.01 \pm 0.029$ & $2.09 \pm 0.008$ & $2.02 \pm 0.011$ \\
\hline G2 & $1.01 \pm 0.069 \mathrm{a}$ & $1.43 \pm 0.123$ & $1.00 \pm 0.095 \mathrm{a}$ \\
\hline G3 & $3.72 \pm 0.207 \mathrm{abc}$ & $2.76 \pm 0.160 \mathrm{~b}$ & $2.51 \pm 0.090 \mathrm{ab}$ \\
\hline G4 & $5.02 \pm 0.305 \mathrm{abc}$ & $2.77 \pm 0.271 \mathrm{~b}$ & $2.36 \pm 0.154 \mathrm{~b}$ \\
\hline
\end{tabular}

All values was expressed as (meen $\pm \mathrm{SE})$

a significant at $\mathrm{p} \leq .05$ in comparison with control group

$\mathrm{b}$ indicates significant difference with $\mathrm{G} 2$

c indicates significant difference between G3 and G4

Table 14: Effect of catechin and EDTA in CAT activity (unit/ min/mg protein) in brain cytosol of lead exposed rats $(n=6)$.

\begin{tabular}{cccc}
\hline \multirow{2}{*}{ Exposed Groups } & \multicolumn{3}{c}{ Post-exposure time (months) } \\
\cline { 2 - 4 } & $1^{\text {st }}$ & $2^{\text {nd }}$ & $3^{\text {rd }}$ \\
\hline G1 & $0.105 \pm 0.013$ & $0.106 \pm 0.009$ & $0.105 \pm 0.010$ \\
\hline G2 & $0.133 \pm 0.014$ & $0.107 \pm 0.017$ & $0.063 \pm 0.005$ \\
\hline G3 & $0.128 \pm 0.007 \mathrm{c}$ & $0.178 \pm 0.012$ & $0.096 \pm 0.005$ \\
\hline G4 & $0.237 \pm 0.021 \mathrm{abc}$ & $0.193 \pm 0.020 \mathrm{ab}$ & $0.140 \pm 0.019 \mathrm{~b}$ \\
\hline
\end{tabular}

All values was expressed as (meen $\pm \mathrm{SE})$

a significant at $\mathrm{p} \leq .05$ in comparison with control group

$\mathrm{b}$ indicates significant difference with $\mathrm{G} 2$

c indicates significant difference between G3 and G4 
Table 15: Effect of catechin and $\mathrm{CaNa}_{2}$ EDTA in G6PD activity (unit/mg protein) in brain cytosol of lead exposed rats $(n=6)$.

\begin{tabular}{cccc}
\hline Exposed Groups & \multicolumn{3}{c}{ Post-exposure time (months) } \\
\cline { 2 - 4 } & $1^{\text {st }}$ & $2^{\text {nd }}$ & $3^{\text {rd }}$ \\
\hline G1 & $5.61 \pm 0.563$ & $5.70 \pm 0.519$ & $5.01 \pm 0.858$ \\
\hline G2 & $6.71 \pm 0.475$ & $4.47 \pm 0.255$ & $6.69 \pm 0.666$ \\
\hline G3 & $11.02 \pm 0.696 \mathrm{abc}$ & $15.31 \pm 0.521 \mathrm{ab}$ & $7.56 \pm 0.509$ \\
\hline G4 & $17.72 \pm 1.31 \mathrm{abc}$ & $13.79 \pm 1.31 \mathrm{ab}$ & $7.70 \pm 0.557$ \\
\hline
\end{tabular}

All values was expressed as (meen $\pm \mathrm{SE})$

a significant at $\mathrm{p} \leq .05$ in comparison with control group

$b$ indicates significant difference with $\mathrm{G} 2$

c indicates significant difference between $\mathrm{G} 3$ and G4

Table 16: Effect of catechin and EDTA in acetylcholinesterase activity (mmol/min/mg protein) in brain cytosol of lead exposed rats $(n=6)$.

\begin{tabular}{cccc}
\hline ExposedGroups & \multicolumn{3}{c}{ Post-exposure time (months) } \\
\cline { 2 - 4 } & $1^{\text {st }}$ & $2^{\text {nd }}$ & $3^{\text {rd }}$ \\
\hline G1 & $1.37 \pm 0.100$ & $1.27 \pm 0.100$ & $1.31 \pm 0.094$ \\
\hline G2 & $0.756 \pm 0.026 \mathrm{a}$ & $0.483 \pm 0.028 \mathrm{a}$ & $0.557 \pm 0.030 \mathrm{a}$ \\
\hline $\mathrm{G} 3$ & $1.00 \pm 0.072 \mathrm{c}$ & $1.54 \pm 0.055 \mathrm{~b}$ & $1.26 \pm 0.098 \mathrm{~b}$ \\
\hline $\mathrm{G} 4$ & $1.66 \pm 0.161 \mathrm{bc}$ & $1.55 \pm 0.134 \mathrm{~b}$ & $1.30 \pm 0.129 \mathrm{~b}$ \\
\hline
\end{tabular}

All values was expressed as (meen $\pm \mathrm{SE}$ )

a significant at $p \leq .05$ in comparison with control group

$\mathrm{b}$ indicates significant difference with $\mathrm{G} 2$

c indicates significant difference between G3 and G4

\section{DISCUSSION}

$\mathrm{Pb}$ is an environmentally persistent toxin that lead to neurological, hematological, gastrointestinal, reproductive, circulatory, and immunological disorders (Patrick, 2006).

Development of anemia in lead toxicity may be attributed to the decreased red blood cell survival because of the increased membrane fragility, reduced RBCs count, decreased hemoglobin production, or summation of all these factors (Rio et al., 2001). In the present study, RBCs count showed significant decrease in G2 after exposure for three months in comparison with the control group which was in agreement with Goneneci et al. (2008). However, RBCs count in G3 showed significant increase after three months in comparison with positive control. This result was in agreement with Miltonprabu and Thangapandiyan (2013) who found that epigallocatechin gallate (one of green tea catechins) improved altered hematological parameters by bringing them back to near normal levels. Also, there is significant increase in RBCs count in G4 after end the 2 nd and 3rd month in comparison with G2. This finding was in agreement with Ashour et al. (2007) who found that CaNa2-EDTA exerted improvements in all hematological parameters and returned their levels to near those of controls.

A significant decrease in $\mathrm{Hb}$ concentration was recorded during the whole period of the experiment in G2 when compared with the control group. Similar result was obtained by Ibrahim et al. (2012). Induction of anaemia by $\mathrm{Pb}$ results from shortening of erythrocyte life span and an inhibition of $\mathrm{Hb}$ synthesis (Mudipalli, 2007). In G3, Hb level showed significant increase all over the experiment period in comparison with G2. This was in agreement with Gad and Zaghloul (2013) who found that $\mathrm{Hb}$ level was significantly increased in rats treated with green tea extract. Moreover it was significantly increased after $2^{\text {nd }}$ and $3^{\text {rd }}$ month of treatment in G4 when compared with G2. Similar result was recorded by Ashour et al. (2007) who found that treatment with $\mathrm{CaNa}_{2}$-EDTA returned $\mathrm{Hb}$ values to near control values.

HCT percent was significantly increased in G3 in all over the experiment period when compared with G2 and after $2^{\text {nd }}$ month in G4 in comparison with G2. In this aspect, Mladenović et al. (2014) reported that administration of epicatechin significantly increased $\mathrm{HCT} \%$ in male Wistar albino rats. $\mathrm{MCV}$ and $\mathrm{MCH}$ values were significantly increased in G3 after three 
months post exposure when compared with G2. This was in agreement with Gad and Zaghloul (2013) who found that hematological parameters were improved in rats treated with green tea.

In the present study, G3 showed increase at WBCs count after 3 months when compared with G2. Gad and Zaghloul (2013) found the same results in rats treated with green tea extract. In G4, a significant increase in WBC count was observed after $1^{\text {st }}$ and $2^{\text {nd }}$ month of exposure in comparison with $\mathrm{G} 1$ and during the whole experiment period when compared with G2 and after $1^{\text {st }}$ and $2^{\text {nd }}$ month when compared with G3. however, Flora et al. (1998) found that WBCs counts were not affected following $\mathrm{CaNa}_{2}$ EDTA administration.

In G3 the NO level showed a significant increase after one month but decrease after three months in comparison to control group and all over the experiment period in comparison to G2. This was in agreement with Mandel et al. (2011) they found that green tea catechins (epigallocatechin gallate) inhibit NOS. Level of NO in G4 showed a significant increase after one month but it was significantly decreased after three months in comparison to G1 and after the $2^{\text {nd }}$ and $3^{\text {rd }}$ month in comparison to $\mathrm{G} 2$. These results were disagree with Flora et al. (2007) who found that $\mathrm{Pb}$ exposure increased NOS expression in brain, which could not be corrected by treatment with DMSA and/or $\mathrm{CaNa}_{2}$ EDTA.

LPO levels in brain showed significant increase in G3 all over the experimental period in comparison to G1 although it was significantly decreased all over the experimental period in comparison to G2. Skrzydlewska et al. (2002) mentioned that green tea extract can decrease lipid peroxidation in rat serum, liver and brain tissues. Moreover, catechins can also interact with phospholipid head groups, particularly with those containing hydroxyl groups, hence they may decrease the fluidity in the polar surface of phospholipid bilayer (Chen et al., 2002). Level of LPO in G4 showed significant increase all over the experimental period in comparison to G1and showed decrease after $2^{\text {nd }}$ and $3^{\text {rd }}$ month in comparison to $\mathrm{G} 2$. In this aspect, Mehta and Flora (2001) found that hepatic LPO was significantly increased by EDTA administration.

Data of the present study indicated that GSH level in the brain tissue of G3 showed significant increase all over the experiment period in comparison with G1 and $\mathrm{G} 2$ and significant decrease after the $3^{\text {rd }}$ month in comparison with G4. This was in agreement with Skrzydlewska et al. (2002) who revealed that green tea extract increases the activities of GPx and GR, and the content of GSH and diminishes the level of LPO in liver and CNS tissues. Level of GSH in G4 showed a significant increase all over the experimental period in comparison with G1, G2 and
G3 (only after three months of exposure). These results were in agreement with Gopal et al. (2009) who reported that $\mathrm{CaNa}_{2}$ EDTA administration caused significant increase in GSH in liver, kidney and muscle and disagree with (Mehta and Flora, 2001) who found that a significant decrease in hepatic GSH by EDTA administration.

SOD activity in brain tissue showed significant decrease after $1^{\text {st }}$ and $3^{\text {rd }}$ month in G2 when compared with control group. Khalaf et al. (2012) found that oral administration of lead acetate induced significant decrease in the activity of SOD in brain.

SOD activity was significantly increased after $1^{\text {st }}$ and $3^{\text {rd }}$ month in G3 in comparison with G1 and all over the experiment period when compared with G2. In this aspect, Al-Rejaie et al. (2012)stated that green tea supplementation bring back the SOD activity to normal in brain cells in stressed animals. A significant increase in SOD activity was found all over the experiment period in G4 when compared with $\mathrm{G} 2$ and after $1^{\text {st }}$ month when compared to G3. These fiding indicated that Co- administration of $\mathrm{CaNa}_{2}$ EDTA was more effective than catechin in improvement of the SOD activity.

In the present work, the activity of CAT in brain tissue showed no significant change in G2 and significantly decreased after $1^{\text {st }}$ month in G3 in comparison with G4. These results disagreed with Antonio-García and Massó-Gonzalez (2008) who found that strong increase of catalase activity in the brain of rats exposed to $300 \mathrm{mg} / \mathrm{L}$ of lead during gestation and lactation and the CAT activity increased in $\mathrm{Pb}$ exposure due to formation of brain lipid hydroperoxides in $\mathrm{Pb}$-intoxicated animals acts as a signal to maintain higher levels of catalase to enhance the triggering of the detoxification process for the metal. In our result CAT activity showed significant increase after $1^{\text {st }}$ and $2^{\text {nd }}$ month in G4 in comparison with $\mathrm{G} 1$ and all over the experiment period when compared to G2 and after $1^{\text {st }}$ month when compared to G3.

The activity of G6PD in brain showed no significant change in G2. This was in agreement with Rogers et al. (1971) who found that G6PD activity was not changed after $\mathrm{Pb}$ intoxication. There was a significant increase in G6PD activity after $1^{\text {st }}$ and $2^{\text {nd }}$ month in G3 in comparison with G1 and G2. This was in agreement with Miltonprabu and Thangapandiyan (2013) who found a significant increase in G6PD activity in rats treated with epigallocatechin gallate. Our result revealed significant decrease in G3 after $1^{\text {st }}$ month when compared to G4. These results in contrast with Pandiyan and Prabu (2014) who reported that Epigallocatechin gallate supplementation resulted in a significant decrease in G6PD activity. Finally, $\mathrm{Pb}$ can result in an increase or decrease in G6PD activity depending on the dose of 
$\mathrm{Pb}$, duration of $\mathrm{Pb}$ exposure, and magnitude of oxidative stress inside the cell (Gelman et al., 1978).

Acetylcholinesterase activity in brain tissue showed significant decrease all over the whole period of the experiment in $\mathrm{G} 2$ in comparison with G1. This was in agreement with Reddy et al. (2003) who observed decrease in the activity of AChE after pbexpousure in both the cerebellum and hippocampus. Exposure to lead alters the release of neurotransmitter from presynaptic never endings. Spontaneous release of neurotransmitter is enhanced probably due to activation of protein kinases in the nerve endings (Sharma et al., 2014). In the present experiment, there is a significant increase AChE activity after $2^{\text {nd }}$ and $3^{\text {rd }}$ month in G3 when compared to G2. However, a significant decrease after $1^{\text {st }}$ month was seen when compared to G4 in AChE activity. These results were in agreement with Rizvi and Zaid (2001) who reported that epicatechin caused an elevation in AChE activity in diabetic erythrocytes but it is incompetable with Kim et al. (2004) who reported that tea polyphenol administration inhibited AChE activity as compared to the control in a dosedependent manner. In G4, a significant increase in AChE activity was observed along the experiment in comparison with $\mathrm{G} 2$ and after $1^{\text {st }}$ month in comparison with G3. This was in agreement with Saxena and Flora (2004) they showed that treatment with $\mathrm{CaNa}_{2}$ EDTA was successful in restoring altered AChE activity towards normal values.

In Conclusion, lead induced microcytic hypochromic anemia in lead treated rats. Administration of Catechin and $\mathrm{CaNa}_{2} \mathrm{EDTA}$ improved the hematological and biochemical parameters. Catechin was more effective than $\mathrm{CaNa}_{2}$ EDTA in improvement of $\mathrm{Hb}, \mathrm{HCT} \%, \mathrm{MCV}, \mathrm{MCH}$ values and NO, LPO parameters, but $\mathrm{CaNa}_{2}$ EDTA more effective than Catechin in improvement of WBCs, lymphocyte, monocyte count and GSH, SOD, CAT activities. AChE activity decreased in lead exposed group but increased in catechin and $\mathrm{CaNa}_{2} \mathrm{EDTA}$ treated groups.

\section{REFERENCES}

Al-Rejaie, S.S.; Abuohashish, H.M.; Ahmed, M.M.; Aleisa, A.M.; Alroujayee, A.S. and Alkhamees, O.A. (2012): Immobilization stress-induced oxidative damage and its amelioration with green and black teas. African Journal of Pharmacy and Pharmacology. 6: 538-545.

Antonio-García, M.T. and Massó-Gonzalez, E.L. (2008): Toxic effects of perinatal lead exposure on the brain of rats: involvement of oxidative stress and the beneficial role of antioxidants. Food and chemical toxicology. 46: 2089-2095.
Ashour, A.E.R.A.; Yassin, M.M.; Abu Aasi, N.M. and Ali, R.M. (2007): Blood, Serum Glucose and Renal Parameters in Lead-Loaded Albino Rats and Treatment with Some Chelating Agents and Natural Oils. Turkish Journal of Biology. 31: 1 .

Babu, P.V.A.; Sabitha, K.E. and Shyamaladevi, C.S. (2006): Therapeutic effect of green tea extract on oxidative stress in aorta and heart of streptozotocin diabetic rats. Chemicobiological interactions. 162: 114-120.

Bechara, E. (2004): Lead poisoning and oxidative stress. in Proceedings of the Free Radical Biology and Medicine. p. S22-S22.

Beutler, E.; Duron, O. and Kelly, B.M. (1963): Improved method for the determination of blood glutathione. The Journal of laboratory and clinical medicine. 61: 882 .

Bokara, K.K.; Brown, E.; McCormick, R.; Yallapragada, P.R.; Rajanna, S. and Bettaiya, $R$. (2008): Lead-induced increase in antioxidant enzymes and lipid peroxidation products in developing rat brain. Biometals. 21: 9-16.

Chen, L.; Yang, X.; Jiao, H. and Zhao, B. (2002): Tea catechins protect against lead-induced cytotoxicity, lipid peroxidation, and membrane fluidity in HepG2 cells. Toxicological sciences. 69: 149-156.

Ding, A.H.; Nathan, C.F. and Stuehr, D.J. (1988): Release of reactive nitrogen intermediates and reactive oxygen intermediates from mouse peritoneal macrophages. Comparison of activating cytokines and evidence for independent production. The Journal of Immunology. 141: 2407-2412.

Ellman, G.L.; Courtney, K.D. and Featherstone, R.M. (1961): A new and rapid colorimetric determination of acetylcholinesterase activity. Biochemical pharmacology. 7: 88-95.

Flora, G.J.; Kumar, P. and Seth, P.K. (1998): Recovery from lead induced biochemical and immunological alterations following combined treatment with DMSA and calcium disodium EDTA in rats. Environmental toxicology and pharmacology. 5: 127-134.

Flora, S.J.; Saxena, G. and Mehta, A. (2007): Reversal of lead-induced neuronal apoptosis by chelation treatment in rats: role of reactive oxygen species and intracellular $\mathrm{Ca} 2+$. Journal of Pharmacology and Experimental Therapeutics. 322: 108-116.

Flora, G.; Gupta, D. and Tiwari, A. (2012): Toxicity of lead: A review with recent updates. Interdiscip Toxicol. 5: 47-58.

Gad, S.B. and Zaghloul, D.M. (2013): Beneficial Effects of Green Tea Extract on Liver and Kidney Functions, Ultrastructure, Lipid Profile and Hematological Parameters in Aged Male Rats. Global Veterinaria. 11: 191-205. 
Gelman, B.B.; Michaelson, I.A. and Bus, J.S. (1978): The effect of lead on oxidative hemolysis and erythrocyte defense mechanisms in the rat. Toxicology and Applied Pharmacology. 45: 119-129.

Gonenci, R.D.A.K.R.; Guzel, R.B.S.C.M. and Atesoglu, M.E.A.E.O. (2008): Effects of high dose lead toxication on liver, kidneys, heart, brain and blood in rabbits: an experimental study. Journal of Applied Biological Sciences. 2: 11-18.

Gopal, R.; Narmada, S.; Vijayakumar, R. and Jaleel, C.A. (2009): Chelating efficacy of $\mathrm{CaNa}<$ sub $>2</$ sub $>$ EDTA on nickel-induced toxicity in $<\mathrm{i}>$ Cirrhinus mrigala $</ \mathrm{i}>$ (Ham.) through its effects on glutathione peroxidase, reduced glutathione and lipid peroxidation. Comptes rendus biologies. 332: 685-696.

Guidotti, T.; McNamara, J. and Moses, M. (2008): The interpretation of trace element analysis in body fluids. Indian Journal of Medical Research. 128: 524.

Gupta, R. (2007): Fipronil. Veterinary toxicology. Basic and clinical principles. Academic Press, New York. 502-504.

Haghighi, B.; Toori, S. and Noie, N. (1998): Shortterm effect of epinephrine on glucose 6phosphate dehydrogenase activity in isolated human hepatocytes. Iranian Journal of Medical Sciences. 23: 37-41.

Ibrahim, N.M.; Eweis, E.A.; El-Beltagi, H.S. and Abdel-Mobdy, Y.E. (2012): Effect of lead acetate toxicity on experimental male albino rat. Asian Pacific journal of tropical biomedicine. 2: 41-46.

Kalia, K. and Flora, S.J. (2005): Strategies for safe and effective therapeutic measures for chronic arsenic and lead poisoning. Journal of occupational health. 47: 1-21.

Kaushik, G.; Satya, S. and Naik, S. (2011): Green tea: protective action against oxidative damage induced by xenobiotics. Mediterranean Journal of Nutrition and Metabolism. 4: 11-31.

Khalaf, A.; Moselhy, W.A. and Abdel-Hamed, M.I. (2012): The protective effect of green tea extract on lead induced oxidative and DNA damage on rat brain. Neurotoxicology. 33: 280-289.

Khan, N. and Mukhtar, H. (2007): Tea polyphenols for health promotion. Life sciences. 81: 519533.

Kim, H.K.; Kim, M.; Kim, S.; Kim, M. and Chung, J.H. (2004): Effects of green tea polyphenol on cognitive and acetylcholinesterase activities. Bioscience, biotechnology, and biochemistry. 68:1977-1979.

Lowry, O.H.; Rosebrough, N.J.; Farr, A.L. and Randall, R.J. (1951): Protein measurement with the Folin phenol reagent. J Biol Chem. 193: $265-275$.
Luck, H. (1963): Catalase in: Bergmer H-U, ed. Methods of enzymatic analysis. Academic press, New York. 885-888.

Mandel, S.A.; Amit, T.; Weinreb, O. and Youdim, M.B. (2011): Understanding the broadspectrum neuroprotective action profile of green tea polyphenols in aging and neurodegenerative diseases. Journal of Alzheimer's Disease. 25: 187-208.

Mehta, A. and Flora, S. (2001): Possible role of metal redistribution, hepatotoxicity and oxidative stress in chelating agents induced hepatic and renal metallothionein in rats. Food and chemical toxicology. 39: 1029-1038.

Miltonprabu, S. and Thangapandiyan, S. (2013): Protective Effect of Epigallocatechin Gallate on Fluoride-Induced Oxidative Stress Related Haematotoxicity in Rats. Reseaech and reviews: Journal of pharmacology and toxicology studies. 1: 1-12.

Misra, H.P. and Fridovich, I. (1972): The role of superoxide anion in the autoxidation of epinephrine and a simple assay for superoxide dismutase. Journal of Biological Chemistry. 247: 3170-3175.

Mladenović, J.M.; Paunović, M.G.; Matić, M.M.; Knežević, V.S.; Ognjanović, B.I.; Štajn, A. ̌́. and Saičić, Z.S. (2014): Copper-induced changes of lipid peroxidation and hematobiochemical parameters in rat blood: Protective role of flavonoids. Archives of Biological Sciences. 66: 1271-1279.

Mudipalli, A. (2007): Lead hepatotoxicity \& potential health effects. Indian Journal of Medical Research. 126: 518

Ohkawa, H.; ohishi, N. and yagi, K. (1979): assay for lipid peroxides in animal tissue by thiobarbaturic acid reaction. Anal.Biochem. 95: 351-358.

Pandiyan, T. and Prabu, M. (2014): Ameliorative effect of epigallocatechin gallate on sodium fluoride induced oxidative stress mediated metabolism in rat. International Journal of Pharmacology and Toxicology. 2: 76-85.

Patil, A.J.; Bhagwat, V.R.; Patil, J.A.; Dongre, N.N.; Ambekar, J.G.; Jailkhani, R. and Das, K.K. (2006): Effect of lead $(\mathrm{Pb})$ exposure on the activity of superoxide dismutase and catalase in battery manufacturing workers (BMW) of Western Maharashtra (India) with reference to heme biosynthesis. International journal of environmental research and public health. 3: 329-337.

Patrick, L. (2006): Lead toxicity, a review of the literature. Part 1: Exposure, evaluation, and treatment. Alternative medicine review : a journal of clinical therapeutic. 11: 2-22.

Piomelli, S. (2002): Childhood lead poisoning. Pediatric Clinics of North America. 49: 1285 1304. 
Reddy, G.R.; Basha, M.R.; Devi, C.B.; Suresh, A.; Baker, J.L.; Shafeek, A.; Heinz, J. and Chetty, C.S. (2003): Lead induced effects on acetylcholinesterase activity in cerebellum and hippocampus of developing rat. International Journal of Developmental Neuroscience. 21:347-352.

Rio, B.; Froquet, R. and Parent-Massin, D. (2001): In vitro effect of lead acetate on human erythropoietic progenitors. Cell biology and toxicology. 17: 41-50.

Rizvi, S.I. and Zaid M.A. (2001): Insuline- like effect of Epicatchin on erythrocyte membrane acetyl choline esterase activity in type 2 Diabetes Mellitus. Clinical and Experimental Pharmacology and Physiology. 28: 776-778.

Rogers, L.E.; Battles, N.D.; Reimold, E.W. and Sartain, P. (1971): Erythrocyte enzymes in experimental lead poisoning. Archiv für Toxikologie. 28: 202-207.

Saxena, G. and Flora, S. (2004): lead-induced oxidative stress and hematological alterations

and their response to combined administration of calcium disodium EDTA with a thiolchelator in rats. Journal of biochemical and molecular toxicology. 18: 221-233.

Sharma, B.; Singh, S. and Siddiqi, N.J. (2014): Biomedical Implications of Heavy Metals Induced Imbalances in Redox Systems. BioMed research international.

Skrzydlewska, E.; Ostrowska, J.; Farbiszewski, R. and Michalak, K. (2002): Protective effect of green tea against lipid peroxidation in the rat liver, blood serum and the brain. Phytomedicine. 9: 232-238.

Soong, W.T.; Chao, K.Y.; Jang, C.S. and Wang, J.D. (1999): Long-term effect of increased lead absorbation on intelligence of children. Archives of Environmental Health: An International Journal. 54:297-301

Sujatha, K.; Srilatha, C.; Anjaneyulu, Y. and Amaravathi, P. (2011): Lead acetate induced nephrotoxicity in wistar albino rats. Apathological, immunohistochemical and ultrastructural studies. International Journal of Pharma and Bio Sciences. 2: 2.

Sutherland, B.A.; Rahman, $R$. and Appleton, $I$. (2006): Mechanisms of action of green tea catechins, with a focus on ischemia-induced neurodegeneration. The Journal of nutritional biochemistry. 17: 291-306.

Thuppil, V. and Tannir, S. (2013): Treating Lead Toxicity: Possibilities beyond Synthetic Chelation. Journal of Krishna Institute of Medical Sciences University. 2: 4-31.

Unno, K.; Takabayashi, F.; Yoshida, H.; Choba, D.; Fukutomi, R.; Kikunaga, N.; Kishido, T.; Oku, N. and Hoshino, M. (2007): Daily consumption of green tea catechin delays memory regression in aged mice. Biogerontology. 8: 89-95.

Xintaras, C. (1992): Impact of lead-contaminated soil on public health.Agency for Toxic Substances and Disease Registy, US Department of.

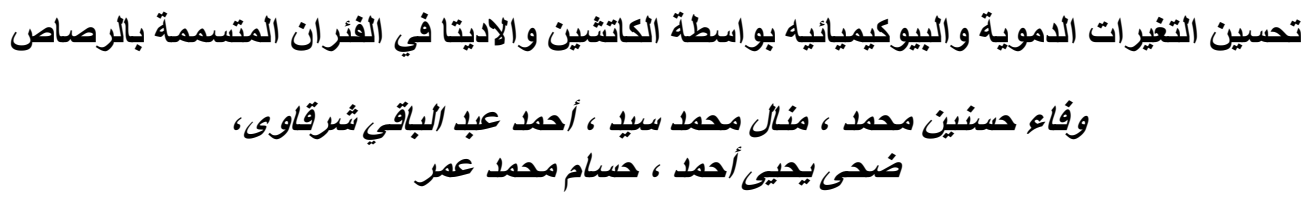

Email: sary64@windowslive.com Assiut University web-site: www.aun.edu.eg

أجريت هذه الدراسة لتقبيم فعالية كل من الكاتثين و الاديتا (CaNa2EDTA) في علاج تسمم الرصاص على الددى الطويل من خلال

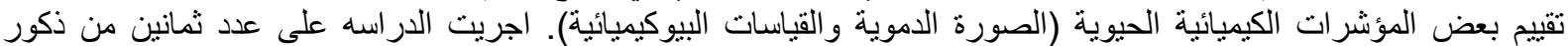

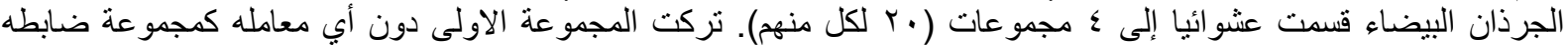

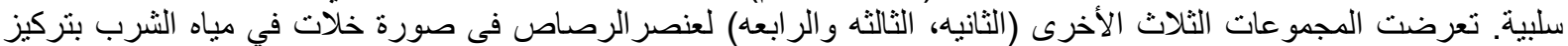

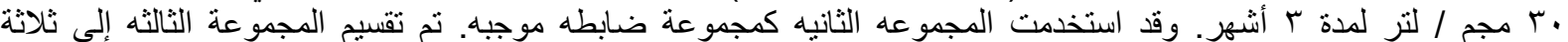

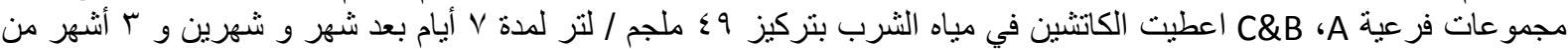

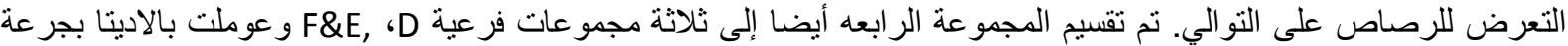

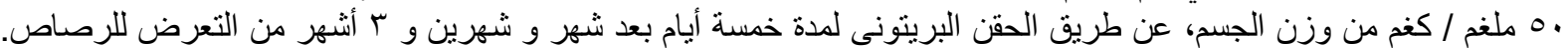

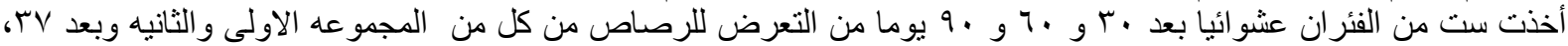

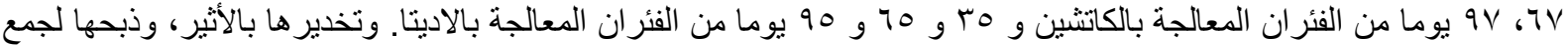

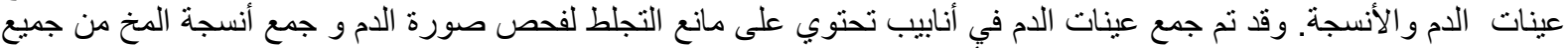

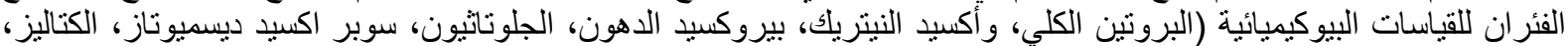

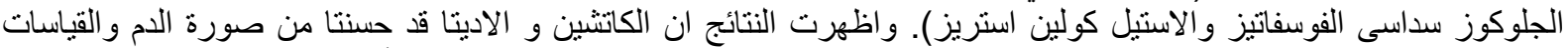

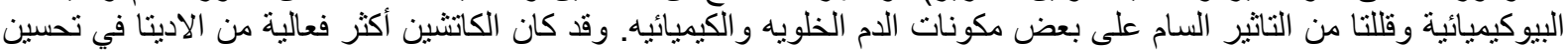

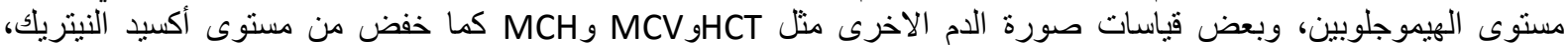

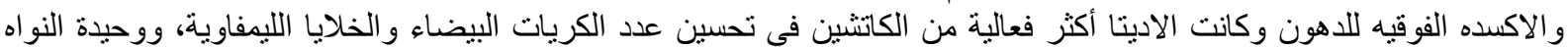
وكذا زيادة مستوى نثاط، الجلوتاثيون، سوبر الادينا أكسيد ديسميونيز، الكتاليز. 